\title{
DENÚNCIAS INQUISITORIAIS: UNIVERSO MÁGICO QUE SE APRESENTA
}

\author{
Helen Ulhôa Pimentel \\ helenulhoa@hotmail.com
}

Resumo: Esse artigo pretende traçar um figurino social dos mágicos denunciados durante as duas primeiras visitas inquisitoriais ao Brasil, em 1591 e em 1618 respectivamente, mas também dos seus denunciantes e dos usuários dos seus serviços. Apresenta também as práticas mais usuais nesse período na colônia e quem eram seus praticantes. Apesar do grande número de denúncias encontradas, muito poucos processos foram instaurados, o que leva a buscar explicações plausíveis para o fenômeno, pois essas práticas eram condenadas pela Igreja, pela Inquisição e pelas leis do reino, cujo cumprimento implicaria a perseguição efetiva a elas.

Palavras-chave: Feiticeiros, Inquisidores, Denúncias.

Encontrar os feiticeiros, curandeiros, enfim, aqueles mágicos que, pretensamente, contavam com poderes sobrenaturais em sua atuação na colônia e saber alguma coisa sobre eles só foi possível seguindo as pistas deixadas pelos seus perseguidores - os inquisidores. Fazia parte da maneira de operar do Tribunal do Santo Ofício inquirir metodicamente, seguindo todos os passos, conforme modo de proceder adequado a cada caso em particular, que era normatizado na forma de um questionário específico. Todas as pessoas inquiridas, como rés ou mesmo como testemunhas, pelo Tribunal da Inquisição, fosse durante alguma visitação ou mesmo em averiguações realizadas por agentes autorizados pelo Santo Ofício, eram perguntadas pela idade, naturalidade, filiação, estado civil, estatuto social e "costumes", além de se submeterem a um teste de conhecimento da doutrina católica, à identificação da origem, pela qual era verificado se eram cristãos-novos ou velhos, estrangeiros, negros, índios e mamelucos.

* Professora da Universidade de Montes Claros - UNIMONTES-, doutora em História pela Universidade de Brasília. Uma primeira versão dessa pesquisa foi apresentada no V Simpósio Internacional de História - Culturas e Identidades - ANPUH/GO, realizado na UFG em 2011. Agradeço ao CNPQ pela bolsa de doutorado, à CAPES pela bolsa Sanduiche em Portugal e à FAPEMIG pelo apoio para participação nesse evento. 
Quando a inquisição chegava a prender e abrir processo contra um réu, começava com a seção in gênere, quando procurava conhecer o réu e seus antepassados, suas relações sociais e seus costumes, passando em seguida para a seção in specie, na qual era o réu era perguntado sobre o tema que o havia levado até ali.

Na seção in gênere, destinada à genealogia, as perguntas procuravam dar conta da inserção social do indiciado. Essas inquirições tinham a função de identificar e localizar o indivíduo na escala de valores da época. Com estas informações era possível avaliar o depoimento sob o ponto de vista de sua credibilidade, pois a sociedade hierarquizada e estamental portuguesa da época, distinguia os de melhor condição social, considerados mais capazes e mais confiáveis.

Tudo era feito de acordo com formulários previamente enviados pelos inquisidores, no caso de pessoas eclesiásticas solicitadas a cooperar com o Santo ofício, ou estavam incluídos nos papéis dos funcionários, que recebiam seus regimentos particulares (aqueles feitos para comissários, meirinhos, etc...) com tudo o que necessitavam para o cumprimento de suas obrigações.

O exame destes dados nos permite conhecer um pouco a sociedade colonial, não apenas no que se refere à condição dos transgressores como também daqueles que os acusavam. Sua leitura resulta num retrato (por vezes bastante embaçado) da gente que habitava o local, alguns dos seus hábitos, um pouco sobre seu conhecimento da doutrina, de sua escolaridade, das suas convicções religiosas, das relações que mantinham umas com as outras, entre outros aspectos de suas vidas.

O direito português estabelecia diferentes estatutos jurídicos nos quais a população estaria encaixada: havia os fidalgos, os homens livres, escravos índios ou negros e libertos, cada qual com suas prerrogativas, porém, o que funcionava perfeitamente no Reino encontrava muitos empecilhos no Brasil. Muitos dos bem sucedidos na colônia, fossem eles brancos ou mestiços filhos de senhores mais importantes, se afidalgavam, muitos negros ou mestiços se "branqueavam" ao se transformarem em senhores de escravos.

O imaginário mágico era uma realidade para todos, qualquer que fosse sua inserção social, mas algumas das suas manifestações, por serem proibidas e penalizadas, transformavam em transgressores os seus praticantes. A ilegalidade de tais atos acabava desestimulando pessoas bem colocadas socialmente, de praticá-los, mas não as impedia de acreditar nos mágicos e de buscar sua ajuda sempre que sentiam necessidade de saber algo do futuro ou de resolver problemas para os quais não conseguiam encontrar soluções legalmente aceitas. 
Também as orações, cerimônias e símbolos cristãos, eram carregados de forças mágicas, porém havia distinção entre o que era permitido, pois pertencia ao corpo doutrinal católico e o que lhe era estranho e portanto, proibido. O demônio, inimigo de Deus, estava presente todo o tempo em toda pregação. Sua força era incontestada e incontestável. Sua realidade não era negada, e suas ações eram procuradas em todos os atos dos homens considerados falhos. Se existia o mal, ele se devia à sua influência e deveria ser exterminado para que Deus vencesse. Conforme a concepção mágica do universo, algumas pessoas possuíam o poder de interceder pelos humanos junto a instâncias sobrenaturais para alcançar algum objetivo. Essas pessoas poderiam atuar em consonância com a Igreja, como os santos, ou de forma desviante, como os feiticeiros, aqui reunidos sob a denominação de mágicos.

$\mathrm{Na}$ busca de pistas sobre os mágicos que atuavam no Brasil durante os dois primeiros séculos de colonização, os Cadernos do Promotor (documentos arquivados sem ordem temática ou cronológica) foram esmiuçados, mas somente depois de consultados 35 deles, seguindo a ordem numérica, sem encontrar nenhuma referência a denúncias contra feiticeiros ou outros mágicos é que apareceu uma resposta a duas cartas, datadas de janeiro de 1643, dando conta da situação calamitosa em que se encontrava o estado do Brasil em virtude do descaso do seu prelado (CAD. PROM. Livro no 228, fls. iniciais sem numeração). A esta advertência, o Conselho Geral respondeu em dezembro de 1645 que, consultando toda a documentação secreta da Inquisição, não foi encontrado nenhum documento com este teor, mas que havia "memória" naquela mesa de que por muitas vezes tinham sido representadas aquelas queixas da devassidão e mau procedimento dos moradores do Brasil em matérias pertencentes ao Santo Ofício.

Segue-se outro documento com instruções para a averiguação de acusações contra Mariana, neta de Esperança Pinheira (que antes constava como não estimando os sacramentos) que dizia não ser possível estar Deus na hóstia consagrada e que ela era feiticeira e usava em suas feitiçarias de corporais e pedras de ara; assim como contra Mônica de Fonseca, também por ser feiticeira e usar das mesmas coisas (CAD. PROM. Livro no 228, fls. iniciais sem numeração). O sumário de testemunhas, tirado então, relaciona mais de trinta pessoas, todas elas relatando práticas ocorridas na Bahia, de feitiçarias, passando por embruxamento de crianças, adivinhações, magia amatória, curandeirismo, etc (CAD. PROM. Livro no 228, fls. 2-103). Esta gama de denúncias nos apresenta um painel bastante ampliado do cotidiano transgressor daquela parte da colônia americana. 
Os documentos constantes destes cadernos não são organizados de acordo com uma ordem cronológica ou temática, por isso, este primeiro localizado não corresponde ao primeiro em ordem cronológica, pois outros mais antigos foram encontrados em Cadernos posteriores. Os documentos mais antigos sobre o tema, no entanto, são os encontrados nos livros da Primeira Visitação do Santo Ofício às Partes do Brasil, de 1591. O mapeamento dos mágicos e da forma como seus poderes eram vistos pela sociedade e pelas instituições encarregadas de sua repressão é o exercício feito a seguir.

De acordo com os registros dos inquisidores que visitaram o Brasil, os feiticeiros coloniais podem ser classificados em sua maioria como gente muito pobre e sem instrução. Em sua maior parte eram mulheres solteiras (também chamadas livres ou de má vida), viúvas, mestiças ou negras, mas havia também muitos homens, normalmente negros ou pardos. Seus denunciantes, e mesmo os usuários de seus poderes, porém, eram de origem variada, pessoas da governança, assim como pessoas comuns e até escravos. Encontramos na documentação vestígios de relações às vezes bastante próximas, outras apenas de ouvir dizer, entre pessoas de extratos bastante diferentes da sociedade. Mesmo no reino, estas aproximações existiram, incluindo dentre os clientes de mágicos tanto eclesiásticos quanto comissários do Santo Ofício e até reis (PAIVA, 2002, p. 173-175). É claro que estas relações garantiam prestígio e poder aos feiticeiros, mas também significavam que aqueles reconheciam seus poderes, necessitavam deles e os temiam.

Nos livros da primeira e da segunda visitação do Santo Ofício ao Brasil, em 1591 e em 1618, encontramos pouca gente confessando delitos de feitiçaria, mas muitos denunciados pelos mesmos. Apenas quatro deste universo foram processados. Todas eram mulheres e pobres. Porque não foram todos processados? A desconsideração dos inquisidores frente a tantos casos significaria desinteresse ou estaria a acenar para objetivos diversos desses?

Os relatos não transparecem nem surpresa nem incredulidade, pelo contrário, parecem constatações da prática de ações reconhecidas como plausíveis, mas sabidamente condenáveis e temerárias. O recurso às denúncias nestes casos parece refletir três medos simultaneamente: o do castigo de Deus, o da Igreja e o dos feiticeiros. De Deus temiam o julgamento final e o fogo do inferno; da Igreja as condenações a tantos tipos de penas espirituais e corporais; e dos feiticeiros temiam os malefícios, que acreditavam, eram capazes de fazer, além de temerem a perda da capacidade curativa que apenas eles podiam oferecer e era tão necessária numa terra com tantas doenças desconhecidas. 
Recorriam às denúncias principalmente aqueles que conheciam melhor as normas da Igreja e também aqueles que se sentiam mais vulneráveis aos feitiços. Este perfil se encaixa melhor em pessoas brancas e de condição social mais elevada, pois eram eles melhor cristianizados e alvos preferenciais da inveja dos marginalizados. O perfil dos denunciados pelo contrário, com pouquíssimas exceções, é formado por pessoas de condição social baixa, com uma incidência muito grande de negros e mulheres.

Nesse artigo foram analisadas apenas confissões e denúncias que não resultaram na instalação de processos. Aparecem práticas como deslocamentos sobrenaturais para locais distantes, metamorfoses, magia amatória, bênçãos, poder de mover coisas, adivinhar paradeiro e fazer vir pessoas, adivinhar futuro, pacto com o Diabo, embruxar crianças, curas e utilização de objetos ou palavras sagradas. Com maior ou menor intensidade, todas essas crenças estavam presentes no cotidiano colonial. Todas tiveram seus agentes, seus usufrutuários, seus denunciantes e seus confessores. As denúncias, mais que os processos - em número muito pequeno para serem significativos -, podem alargar o panorama das práticas mágicas e de seus praticantes.

Estas confissões e denúncias que na maior parte das vezes não resultavam na implementação de um processo nem na punição aos desviantes, em muitos casos eram contra feiticeiros que, apesar de atuarem na colônia, tinham vindo degredados, mas que aqui, viviam sem nenhum controle exercido pelos que os condenaram. Nos livros do Santo Ofício encontramos referências a muitos destes, que engrossaram a população principalmente urbana e que continuavam a escandalizar pelo seu comportamento e a praticar seus delitos. Exemplar foi o caso de Lianor Soares que veio degredada de Portugal e aqui continuou com sua fama de feiticeira. Foi denunciada por D. Lúcia de Mello, de 60 anos, natural da ilha Graciosa, que ouviu do Cônego da Sé, Gaspar Leitão, que ela virava borboleta, colocava quebranto e se transportava rapidamente por grandes distâncias, pois tinha ido a Portugal na noite de uma briga e, na mesma noite, voltou trazendo a notícia, sem que sua ausência fosse notada (MENDONÇA, 1925, p. 342-343).

A denunciante e seu informante pertenciam ao grupo dos respeitáveis. Ela era branca e idosa e ele era uma autoridade eclesiástica. Ambos viam com desprezo o comportamento da denunciada, mas revelaram medo e crença em seus poderes. Este cônego sabia de todas as atividades da feiticeira, ou porque mantinha relações com ela, ou com alguém ligado a ela, ou mesmo por boatos, mas isso indica que havia intercâmbio entre as esferas sociais na colônia. Aliás, além da bisbilhotice propiciada pelo tipo de organização 
urbana, em comunidades tão pequenas é muito difícil as pessoas não se conhecerem, não ficarem a par do que acontece com as outras e não interferirem umas nas vidas das outras.

Estas interferências poderiam se dar na forma de proteção por parte de quem tinha poder, fosse ele político, religioso ou mágico, provocando uma relação de intensa troca. Os que não conseguiam proteção viviam sob a pressão do medo. Numa época em que a invocação de causalidades sobrenaturais continuava a fazer parte do quadro explicativo da ordem do universo, os feiticeiros eram considerados seres muito poderosos.

Semelhante à denúncia anterior, consta que Margarida Guomez disse um dia que "havia grandes trabalhos em Portugal" e que Maria Vicente, velha quase cega, para quem ela havia dito aquilo, logo soube que naquele dia os castelhanos entraram em Lisboa (MENDONÇA, 1925, p. 395).

Isabel Rodrigues, de alcunha Boca-torta, sofreu inúmeras acusações. Um negociante com o qual tinha tido desentendimentos disse que ela se vingou fazendo com que ele lançasse pela boca um grande pedaço de sangue e ele tinha ouvido dizer que ela falava "com os diabos," (MENDONÇA, 1925, p. 318-319) o que teria levado a grande desconfiança e temor. Sobre ela ainda se dizia que se transformava em pata,( MENDONÇA, 1925, p. 396) que via e ouvia o que se passava em Lisboa (MENDONÇA, 1925, p. 412) e que fazia magia amatória, confeccionando carta de tocar (MENDONÇA, 1925, p. 433), que teria o poder de atrair o amor da pessoa tocada por ela. Nenhuma destas denúncias foi averiguada, mas ela despertava o temor de gente de várias posições sociais.

Apesar de pouco comum, algumas senhoras que recebiam o tratamento de donas, por serem dignas de consideração, foram também denunciadas. Sobre D. Mécia, mulher de Francisco d'Araujo e Dona Isabel, mulher de Cristóvão de Barros (MENDONÇA, 1925, p. 413), foi dito que havia "quatro anos pouco mais ou menos que de noite no caminho de Vila Velha foram achadas em feitiçarias". Outra denúncia feita contra senhoras parece se referir ao mesmo fato, mas que, por ter se passado há muito tempo foi deturpado talvez por lapso de memória. Segundo ela

Nesta cidade havia mulheres que foram achadas... em figura de patas as quais eram Violante Ferreira, tida por cristã-velha de geração nobre, mulher de Francisco Fernandes Pantoja escrivão que foi dos contos nesta cidade e Dona Mécia Pereira cristã-velha mulher de Francisco d'Araujo e Paula de Sequeira cristã-velha mulher de Antonio de Faria contador nesta cidade (MENDONÇA, 1925, p. 479) 
Estas senhoras, todas bem colocadas na sociedade, podem realmente ter sido vistas praticando magias fora da cidade, mas podem ter sido vítimas de inveja e denunciadas por pessoas que queriam vê-las perseguidas, assim como podem também ter usado a crendice popular para se imporem como possuidoras de poderes mágicos, e despertarem temor e/ou admiração. A invocação de mulheres se deslocando metamorfoseadas em figura de animais remetia a crenças em ajuntamentos de bruxas que em Portugal foram pouco consideradas (PAIVA, 2002, p. 41-47). No Brasil encontramos pouquíssimas referências a essas metamorfoses, mas não parece que para os denunciantes havia distinção entre esses efeitos e qualquer outro considerado sobrenatural. Estes casos foram relatados como frutos de feitiçarias que elas foram pegas fazendo.

A confissão de Paula Siqueira (MENDONÇA, 1935, p. 104-114), cristã-velha, natural de Lisboa, casada com Antonio Faria, contador da fazenda Del rei, 40 anos e moradora em Salvador, feita no tempo da graça não resultou em processo, pois, consta nas margens do livro de confissões que ela, manifestando arrependimento, foi mandada embora apenas com admoestações e penitências espirituais. No entanto ela sofreu dois processos (INQ. DE LISBOA. Proc. n 3306 e 3307), provavelmente decorrentes de outras denúncias de que fora vítima. Foi ré em um processo junto com Felipa de Souza pelo delito de sodomia que ela chegou a confessar no tempo de graça e em outro por ter lido o livro proibido Diana, de Monte Mayor, coisa a que ela não se refere em sua confissão. Os delitos de sodomia mereciam normalmente mais atenção quando eram praticados por homens e os livros "defesos" contidos nos famosos róis elaborados pela Inquisição não deveriam ser lidos, pois seus ensinamentos eram prejudiciais à moral e à doutrina cristãs e este era um assunto que recebia grande atenção dos inquisidores.

Suas declarações de ter aprendido, ensinado e usado magia amatória para conseguir a afeição do seu marido, não mereceram a mesma atenção. Teria aprendido uma das fórmulas com o clérigo Gaspar Franco, já morto, que tinha sido capelão del rei, cujo irmão era casado com uma sua cunhada. Outras lhe foram ensinadas por Isabel Rodrigues, a Boca-Torta, e incluíam dizer algumas palavras que nomeavam as estrelas e os diabos dentre outras coisas supersticiosas e uma carta de tocar sobre a qual deveriam ser ditos "três evangelhos". Essa função foi cumprida por Mécia Dias, uma velha casada com Jorge Fernandes Freire, que colocou o papel sob o toucado e procurou três padres para que dissessem sobre ela "o evangelho" antes de devolvê-lo à sua dona. Beatriz de Sampaio, casada com Jorge Mascarenhas, moradora em Matoim, lhe ensinou umas palavras que deveria dizer andando em cruz, 
atravessando a casa. Maria Vilela, natural do Porto e casada com Miguel Ribeiro, ensinou a usar pedra de ara moída no vinho do seu marido, seguida de algumas palavras e depois fez junto com ela a oração de Santo Erasmo que era muito utilizada em Portugal e para este período no Brasil, foi encontrada apenas esta vez. Esta oração era realizada seguindo um cerimonial e a "devoção" usava imagens fortes para transmitir as ameaças e a força do desejo da pessoa que recorria ao sobrenatural na busca da sua concretização.

As práticas mágicas visando influenciar o comportamento dos maridos/amásios eram muito comuns. Os processos parecem indicar que, em muitos casos o tratamento dedicado pelos homens às mulheres era bastante brutal, e que as mulheres maltratadas colocavam todas as suas esperanças em magias que pudessem moldar as vontades e os humores de seus maridos.

Catarina Fróes (MENDONÇA, 1935, p. 119-121), meio cristã-velha, de 50 anos, casada com Francisco de Morais, que serviu em Salvador de escrivão e meirinho, confessou que pediu por duas vezes a Maria Gonçalves, de alcunha Arde-lhe-o-rabo, uns feitiços, ambos solicitados por suas filhas, uma casada com Gaspar Martins, lavrador, morador em Tassuapina e que estava no momento na guerra de Sergipe, e outra casada com Antonio Dias, cristão-velho, carpinteiro de navios. Ambas queriam ser bem tratadas pelos maridos, mas acabaram desistindo de utilizar os pós de magia amatória conseguidos. Ela confessa que tanto ela quanto suas filhas entendiam que para a pretensão que tinham, "os feitiços se haviam de fazer com intervir o diabo e arte sua" e, por isso procuraram a feiticeira que tinha fama de ter pacto com o Diabo. A confidente, apesar de reconhecer que tinha conhecimento da transgressão em que incorria, não foi processada, já a feiticeira que ela delatou o foi. É verdade que não foi apenas esta a denúncia sofrida por Arde-lhe-o-rabo, mas, como vimos, poucas foram as denúncias contra estas práticas que resultaram na abertura de um processo.

Os três maridos citados, o da mãe e os das filhas, tinham ofícios e as mulheres eram suas dependentes. Apenas a mãe não demonstrara insatisfação para com o tratamento que recebia. A única mulher sozinha citada é a feiticeira que, conforme declara, vive do que lhe dão para realizar as vontades dos fregueses. Esse tipo de mulher com certeza era considerado um peso para as outras pessoas, pois não tendo ofício de que viver alardeava poderes que lhe renderiam a subsistência.

Guiomar de Oliveira (MENDONÇA, 1935, p. 132-140), natural de Lisboa, de 37 anos, casada com Francisco Fernandes, cristão-velho, sapateiro, confessou que hospedou uns quatro anos antes uma degredada que tinha conhecido como taverneira, já viúva, fazia quinze anos em Portugal. Essa 
mulher, Antonia Fernandes, de alcunha a Nóbrega, era natural de Guimarães, de idade por volta de 50 anos e veio para o Brasil degredada por alcovitar a filha. Contou à sua hospedeira que falava com os diabos e que podia ensiná-la feitiços para melhorar o tratamento que recebia do seu marido. Ela testou todos os ensinamentos sabendo que eram diabólicos e achou que surtiram efeito. A mesma Nóbrega a estimulou também a conquistar um clérigo da Sé para conseguir com ele os óleos do batismo que ela tanto desejava, mas isso ela não aceitou fazer.

Uma confessa alcoviteira foi recebida em casa de família, ofereceu seus serviços para beneficiar sua hospedeira, mas também a estimulou a fazer parte do seu jogo e conseguir o almejado óleo de batismo. O primeiro delito, mesmo contendo pacto implícito com o demônio, não foi considerado indigno pela mulher casada, pois lutava pelo seu casamento, já a proposta de sedução do clérigo não foi aceita. Como se vê, é difícil delimitar as práticas mágicas, colocá-las dentro de determinados contornos sociais, pois a frágil cristianização dos fiéis e os limites muito fluídos entre o natural e o sobrenatural faziam com que fosse difícil separar o lícito do ilícito e, portanto o que era aceitável socialmente e o que não o era, o que era digno do que não o era.

Uma mulher já morta, de alcunha Mija-vinagre, foi denunciada por uma moça de boa posição social que havia recorrido a ela em busca de uma magia para que seu pai aceitasse seu casamento (MENDONÇA, 1925, p. 395), e Gaspar Gonçalves, de alcunha Abahi, foi denunciado por um licenciado em artes, porque, por meio de magia amatória, fazia e desfazia bem querer (MENDONÇA, 1925, p. 460). Estes dois feiticeiros que inclinavam vontades eram procurados inclusive por gente de alta condição social como são os dois sujeitos citados acima e estas pessoas não demonstravam a menor dúvida com relação à eficácia dos denunciados.

Uma confissão que chama a atenção foi feita por João Rodrigues Palha (MENDONÇA, 1935, p. 251-252), cristão-velho, natural da vila de Moura, de 62 anos, casado com Mécia de Lemos, lavrador no engenho de Bernardo Pimentel. O que torna mais interessante esse caso é o fato dele ser o pai de frei Vicente do Salvador, que veio a ser considerado o primeiro historiador do Brasil. ${ }^{2}$ Ele confessou ter feito, ainda em Portugal, uma benção muito usada pelos pastores para os bichos caírem do gado. Entendia que "nisto havia contrato com o diabo", mas que nunca deixou a fé de Cristo. Ele era pessoa simples, mas muito religiosa. Como a prática era usual no meio em que vivia, mesmo atribuída ao Diabo, ele não a considerava afronta à Igreja, o que demonstra o quanto a cultura cristã era eivada de crenças pagãs de uma maneira tão profunda que não eram sentidas como tal. 
André - descrito como escravo boçal da Guiné - foi denunciado pelo seu dono por mover coisas do lugar com os olhos e adivinhar paradeiro de negro fugido (MENDONÇA, 1925, p. 295). Não foi uma prática muito comum os donos denunciarem seus escravos, o que torna esta denúncia excepcional, sintomática ou de grande zelo religioso, ou de medo muito grande do que este escravo poderia fazer contra ele. Será que ele aceitaria inclusive que seu escravo fosse preso? Ou esperava que uma boa lição dos inquisidores o amedrontasse o suficiente para neutralizar sua força?

Outra feiticeira denunciada pelo poder de mover coisas foi Catarina Rodriguez, de alcunha Tripeira, de quem foi dito que "fizera saltar fora de uma caldeira um peixe vindo de Portugal” (MENDONÇA, 1925, p. 396). Sobre ela não são dadas maiores informações, mas foi registrado seu poder.

Um negro velho (TEIXEIRA, 1963, p. 451-452), escravo dos padres do mosteiro de São Francisco, foi denunciado pelo barbeiro Francisco Nogueira, de 30 anos, casado, natural de Lisboa. Foi dito que ele era feiticeiro e o ajudou por duas vezes a encontrar uma escrava fugida. O denunciante disse que recorreu a este artifício sem saber que ofendia à Igreja católica, tanto que depois que o soube, fugindo-lhe outra negra não recorreu a nenhum feiticeiro. Verdade ou não, foi o argumento utilizado para se mostrar fiel aos preceitos da Igreja, o que não invalida sua crença: o negro conseguia saber do paradeiro de pessoas escondidas. Pelas informações contidas nesta denúncia, este escravo dos padres era procurado com grande freqüência e isto não devia passar despercebido de seus senhores. O que levava os padres à conivência com estas práticas? Ao processo de naturalização que sofriam devido à freqüência com que ocorriam, não causando mais espanto ou escândalo? O fato de compartilharem as mesmas crenças e de acharem que com elas era possível ajudar a resolver os problemas dos outros senhores?

Isabel Montija (MENDONÇA, 1925, p. 396), sobre quem não foram dadas maiores informações, adivinhava o paradeiro das pessoas, o que também era feito por Anna Fernandes (MENDONÇA, 1925, p. 307), mulher do feitor Antonio Roiz, cuja prática foi descrita como uma devoção com a qual "fazia vir uma pessoa donde quer que estava se era viva ao terceiro dia e se era morta que lhe aparecia um vulto". Em um tempo como aquele vivido por estas personagens, em que as viagens marítimas eram constantes, praticamente todas as famílias possuíam pessoas embarcadas em alguma viagem e com possibilidades grandes de nunca regressarem. $\mathrm{O}$ destino podia ter sido a morte, ou o desaparecimento por estar perdido em algum local distante ou mesmo por ter encontrado algum atrativo especial em outros locais, levando à opção por não retornar à casa. Com a vida em suspenso, 
sem saber o paradeiro de entes queridos, era muito constante o recurso às pessoas que, segundo criam, conseguiam adivinhar onde estavam, se vivos ou mortos, e se sua volta seria breve. Estas adivinhações eram solicitadas por pessoas de todos os estratos sociais, pois estavam todos igualmente sujeitos às mesmas aflições.

Em Olinda, José André Magro (MENDONÇA, 1929, p. 98-99), 40 anos, viúvo, preso na cadeia pública por assassinato, foi levado à mesa da Inquisição para aliviar sua consciência. Ele era licenciado e fidalgo de linhagem. Havia sido preso em outra ocasião, há quatro anos, por dizerem que estava a serviço de Dom Antônio do Crato, ${ }^{3}$ ocasião em que Brízida Lopes "vendedeira mulata", conhecida nesta vila por feiticeira, teria adivinhado o que lhe sucederia. Ele disse que inicialmente não acreditara nas suas predições de que seria embarcado de volta para Portugal, pois tinha a palavra do ouvidor, negociada por via dos padres da Companhia de que ficaria no Brasil.

Pelo acerto das previsões da mulher, passou a considerá-la feiticeira, apesar dela ter dito que uma sua amiga é que fizera as feitiçarias para adivinhar o destino do fidalgo. Suas denúncias são confirmadas por outra testemunha (MENDONÇA, 1929, p. 320-322), que era sua vizinha e que também se encontrava na prisão e ouviu as previsões feitas por ela. A testemunha, aproveitando, relata ainda que ouviu dizer, que Brízida estava sendo investigada no juízo eclesiástico por feiticeira. Esta é mais uma denúncia envolvendo pessoas de condição social diferenciada. Um fidalgo que se relacionava com padres da Companhia e obtinha privilégios concedidos pelo ouvidor, confirmava o poder de adivinhar da feiticeira, mas também encontramos referência à atuação do eclesiástico com relação ao delito de feitiçaria, parecendo que este atuava de maneira efetiva neste controle.

O Diabo é referido claramente em algumas denúncias. Na da mulata Beatriz Correa (MENDONÇA, 1925, p. 385 e 413), denunciada duas vezes pelos mesmos delitos, foi dito que "com arte do Diabo" tinha três cobras em uma botija e que tinha feito o navio em que viajava, degredada para o reino, "arribar". Este termo era usado para relatar a ação de um navio ser obrigado a retornar ao porto de saída por não conseguir condições de navegação. Essa mesma mulata é acusada em outro processo (INQ. DE LISBOA, Proc. $\mathrm{n}^{\circ}$ 10776), no testemunho de Paula de Almeida, por estas mesmas práticas, porém com o acréscimo de uma informação passada por D. Margarida, mulher de Fernão de Ataíde, senhor de engenho em Jaguaripe, incriminado no caso da Santidade indígena. Esta havia dito que Beatriz Correa havia enviado a seu marido "um bucho de peixe recheado com coisas de feitiçaria... e o trazia inquieto." 
Continuando com as denúncias envolvendo pacto com o Diabo, consta que uma filha de uma mulher conhecida como Nóbrega (MENDONÇA, 1925, p. 423-424), que morava em Lisboa, segundo seu acusador João Ribeiro, tinha um demônio "familiar" 4 em um anel e praticava magia amatória. Ele acreditava que este diabinho costumava fazer tudo o que ela pedia. Como esta Nóbrega veio degredada do reino por alcovitar sua filha, podemos classificar a ambas como marginais na sociedade da época, da mesma maneira que Borges (MENDONÇA, 1925, p. 527), uma portuguesa que estava em Pernambuco e foi referida como "uma mulher alta de corpo... solteira," que tem fama pública por ser reconhecida como "grande feiticeira pelo poder do Diabo". Leonor Martins (MENDONÇA, 1929, p. 108-109), de alcunha a salteadeira, mulher que não tinha marido e que tinha sido degredada do Reino pelo crime de feitiçaria, foi acusada de ter na "ilharga esquerda no vazio junto da costa fundeira”, uma concavidade metida para dentro na própria carne com uma figura de rosto humano em alto relevo que ela dizia ser um "familiar". Além disto ela trazia consigo uma série de objetos mágicos para induzir bem querer. Domingas Brandoa (MENDONÇA, 1929, p. 121-122), casada com um homem de sobrenome Rolim, foi acusada de adivinhar. Para isto fizera na cadeia onde estava presa, uma cerimônia com uma vassoura e informou que no dia seguinte havia de ser solta por uma determinada pessoa, o que de fato aconteceu. Em outra ocasião chamou por Barrabás e outros demônios para adivinhar se uma pessoa iria se casar. Há a indicação de que ela costumava andar "tomada de vinho", mas que não estava assim quando fez as referidas adivinhações.

Antonio Guedes (MENDONÇA, 1925, p. 396), outro denunciado por tratar com o demônio, era escrivão, o que o transforma em um delatado diferente da maioria. Ele teria respondido a alguém que lhe pedia “... que lhe ensinasse a trejeitar" como ele sabia fazer, que era "necessário dar uma nádega ao Diabo". Essa explicação, mesmo que fosse uma troça, envolvia a crença de que o Diabo cobrava pelos ensinamentos que dava e que mesmo alguém de boa posição poderia conseguir realizar coisas com o auxílio da força do mal.

Antonio da Costa (TEIXEIRA, 1963, p. 446-448), cristão-velho, 35 anos, natural do arcebispado de Braga, casado e morador na cidade de Salvador, confessa uma série de delitos: ter trasladado um livro de "chiromancia judiciária”; ter pedido a Ana Coelha que lhe adivinhasse quem havia furtado em sua casa; ter chamado dois negros escravos para curar uma de suas filhas, e outro escravo de Inês de Barros para curar um negro de Pedro Alvares Aranha; e ter consultado um moleque chamado Bartolomeu, de 12 
anos que adivinhava e era escravo de Luís Mendes Pinto, cristão-novo. Sua confissão envolve a denúncia de muitas pessoas.

Com relação ao livro de chiromancia, diz que lhe foi emprestado por Brás Sarmento, cristão-velho e solteiro, e passado por ele para as seguintes pessoas: João Andrade, cristão-velho, casado e inquiridor, Domingos de Andrade, escrivão dos Agravos da Relação desta cidade, Baltasar Nogueira, mameluco "homeziado" nesta cidade, Pedro Álvares Aranha, casado e o capitão Gonçalo Bezerra de Mesquita, casado nesta cidade com D. Maria.

O uso do livro de horas para adivinhar era, segundo ele, muito generalizado, não tendo seu ato provocado escândalo, pois era prática muito comum nesta terra. Além de Ana Coelha ele afirma saber que também o utilizavam D. Brites, mulher de Domingos de Andrade e outra D. Brites, mulher de Antonio da Motta, escrivão do fisco. Pela confissão de Maria de Penhosa (TEIXEIRA, 1963, p. 449), cristã-velha de 50 anos, natural de Ilhéus, ficamos sabendo que também ela fazia a sorte do livro de horas para adivinhar futuro. Ela disse ter aprendido com duas mulheres já mortas, Ana Coelha, que era mulher de Domingos Preto, carpinteiro e Madanella de França, que foi mulher de André Cardoso, marinheiro. Ela disse que pensou que adivinhar quem fazia furtos era obra de Deus e não do demônio, e que se soubesse que era proibido não teria feito.

Para o imaginário da época, poder sobre as condições do tempo, sobre saberes e sobre animais peçonhentos, só possuía aquele que tinha algum pacto com o demônio. Destes, alguns eram acusados até de possuírem diabinhos particulares que os acompanhavam todo o tempo e realizavam todos os seus desejos. $\mathrm{O}$ que podemos perceber nestas últimas denúncias é uma verdadeira teia em que havia tantos envolvidos, e de tantas "qualidades" que nos dá idéia de que estas práticas não ficavam restritas a pequenos grupos e sim de que eram feitas às claras, à vista de quem quisesse e para resolver o problema que aparecesse. Os letrados recorriam a práticas mais sofisticadas que envolviam escritos, os analfabetos à tradição oral, mas todos passavam adiante seus saberes.

A mortalidade infantil deixava inconformadas muitas famílias que reagiam buscando as causas da morte de crianças que aparentavam saúde perfeita, e portanto condições de vida. Qualquer pessoa, dentro ou fora do círculo de amizade poderia ser responsabilizada, desde que tivesse se aproximado da criança ou manifestado algum comportamento estranho. Joana Ribeiro, cigana, foi acusada de "embruxar" um menino que nasceu "empelicado" (MENDONÇA, 1925, p. 303). Da mesma forma, uma mulher depois de morta foi denunciada por um padre jesuíta por ter, com seus 
poderes mágicos, "embruxado" seu irmão de cinco dias de nascido que apareceu "com a barba chupada e em acabando de o batizarem morreu" (MENDONÇA, 1925, p. 350). Ana Jacome (MENDONÇA, 1929, p. 25-26), torta de um olho, mulher que não tem marido, com a qual a denunciante nunca tinha falado, mas que tinha ouvido dizer que era feiticeira, é acusada de ter embruxado uma criança. A crença na maldade das feiticeiras, capazes de matar crianças, que tivessem nascido com algum sinal distintivo ou não, era bastante generalizada. Vimos acima que se incluía nesse universo de crença até um padre da Companhia de Jesus que também denunciou o embruxamento de seu irmão, coisa na qual, com certeza acreditava. As acusadas eram normalmente de baixa condição social, em sua maioria solteiras ou viúvas, costumavam ser identificadas por algum defeito físico, e muitas vezes tinham problemas de relacionamento com a família da criança. As vítimas, porém, eram de condição social variada, desde pessoas consideradas a escravos.

Outras denúncias constantes eram com relação a curandeiros que, segundo consta, conseguiam resolver problemas fora do alcance inclusive dos médicos que, por sua vez, eram pouco instrumentalizados e em pequeno número. Para essas curas utilizavam algumas ervas, mas havia sempre o acompanhamento de cerimônias e rituais interpretados pela Igreja como supersticiosos. Os agentes de práticas mágicas que procediam a curas podiam ter várias designações como curandeiros, feiticeiros, mezinheiros.

Um velho de alcunha "Quatro-olhos" (MENDONÇA, 1925, p. 318) e uma moradora no Monte Calvário, de alcunha Mineira (MENDONÇA, 1925, p. 319), cujo nome não foi lembrado, foram denunciados por realizar curas com ervas "pela arte do Diabo". João Poré (TEIXEIRA, 1963, p. 457) era flamengo, mas cristão-velho de pai e mãe. Tinha 30 anos e era solteiro. Confessou ter feito e ensinado a superstição aprendida com uns italianos para curar dor de dente. Consistia em tocar o dente causador da dor com um prego novo, com o qual deveria depois escrever na parede o nome Macabeus "e se o dito dente é da parte direita pregar o dito prego no primeiro A do nome, e se o dito dente que dói é da parte esquerda, pregá-lo no último A".

O único feiticeiro morador no campo de que as primeiras visitações deram notícia, foi o negro forro Francisco Cucana (TEIXEIRA, 1963, p. 453) que vivia em local próximo a um engenho do recôncavo baiano e era famoso curador. Seu denunciante, Pero de Moura, era cristão-velho, nascido em Lisboa, 30 anos, casado e morador na cidade de Salvador. Ele reconhece que sabia ser proibido pela Igreja este tipo de cura, mas frente à situação em

Hist. R., Goiânia, v. 17, n. 1, p. 185-202, jan./jun. 2012 
que se encontrava seu irmão "fizera pouco escrúpulo disso pelo pouco que nesta terra se costuma fazer de semelhantes coisas".

Um gentio feiticeiro (MENDONÇA, 1925, p. 536), utilizava método diferente e curou a Domingos Ferreira que se queixava de doerem-lhe os pés, "de uma frialdade". Chupando-lhe este as partes afetadas, no dia seguinte estava novamente andando. A cura dependia de conhecer o mal que afetara o doente e para isso consideravam que era necessário descobrir que feitiço tinha sido feito e quem o fizera. Por isso um escravo, negro da Guiné (MENDONÇA, 1925, p. 548) e cristão foi denunciado por adivinhar "coisas feitas e com certas palavras faz andar e mover umas tigelas de barro branca”. Assim conseguiam resposta sobre quem havia feito o feitiço. As duas últimas curas delatadas envolviam procedimentos menos convencionais, não usando ervas nem procedimentos de eficácia reconhecida. Os mais convencionais procediam de maneira muito parecida com a dos médicos que além de usar as famosas mesinhas também recorriam a algumas orações.

O processo de chupar era muito característico de indígenas e descobrir coisas feitas, que significa descobrir malefícios feitos contra alguém, era mais tipicamente procedimento africano. Curadores índios e negros eram os mais procurados, e foi nesta prática que encontramos maior número de homens atuando. As doenças tropicais com certeza eram melhor conhecidas pelos que eram originários de locais com o tipo de clima existente no Brasil, o que fazia com que os médicos europeus ou os curandeiros oriundos de Portugal encontrassem maior dificuldade para enfrentá-las e obtivessem menos êxito em suas ações. Nestes casos eram solicitados aqueles curandeiros que haviam se tornado famosos e que eram predominantemente escravos ou libertos.

A confissão de Joana Correa (TEIXEIRA, 1963, p. 525), cristã-velha de 52 anos, natural do Brasil (é referida como "dona viúva" na confissão, o que é indicador de posição de respeito) é interessante, pois suas mestras são duas irmãs "da nação" que ensinaram que pedra de ara moída poderia ser o remédio que ela queria para fazer com que seu genro deixasse de dar má vida a sua filha. Como esta pedra tinha a virtude de dar a seu possuidor "ventura" e "mercês de Deus", as irmãs de origem judaica pediram que ao conseguir a pedra, lhes desse também umas lascas, indicando que crenças pagãs informavam não apenas o imaginário cristão, mas também o judaico, ou que esse estava contaminado por aquele.

Estas denúncias que não resultaram em processos, não trazem tantas informações quanto esses, mas permitem algumas leituras sobre seus agentes. Parece haver alguma divisão de funções entre eles, pois aparecem muitos homens exercendo o papel de curandeiros, enquanto só mulheres embruxavam 
crianças e a magia amatória era predominantemente feminina, apesar de alguns homens também se aventurarem neste campo. A adivinhação era feita pelos dois igualmente e a proteção feita por meio de orações escritas e bolsas de mandinga era mais exercida pelos homens.

Como encontramos todo tipo de gente envolvida em fazer ou usufruir de práticas mágicas, não podemos deixar de frisar que elas eram denunciadas para atender a solicitações da Igreja, mas que nem os usuários nem as autoridades as consideravam efetivamente perniciosas. Essas conclusões apóiam-se na longa lista de delitos confessados e denunciados que exploramos acima, todos eles decorrentes das duas visitações inquisitoriais ao Brasil, abrangendo um período de sete anos apenas, e que não resultaram em mais do que quatro processos contra feiticeiras.

Outra conclusão a que as denúncias nos permitem chegar é que apesar de não terem sido muito perseguidas, as práticas mágicas eram extremamente populares na colônia, não havendo quem não as conhecesse ou usasse para qualquer fim que fosse. Inegável, portanto, é a crença nestes poderes sobrenaturais no imaginário colonial. Inegável também é que a Inquisição tinha conhecimento sobre o que se passava no Brasil. A existência de um número de denúncias muito superior ao de processos indica que os inquisidores estavam preocupados, sobretudo, com judaizantes cristãos-novos e que eram céticos em relação a parte do que lhes era relatado. A distância em que se encontrava o Brasil tornava os processos muito caros fazendo com que procurassem concentrar seus esforços naqueles que consideravam mais importantes. Em alguns casos utilizavam o processo de maneira exemplar, como meio de intimidação dos fiéis e de marcação de posição frente a determinados delitos.

Mas enfim, o que efetivamente levava os inquisidores a punirem ou não determinados delitos ou pessoas que os praticavam? Até aqui temos indicadores da abrangência social destas ações, do grande número de práticas mágicas utilizadas na colônia e da quantidade de gente envolvida, como praticante ou como cliente. Porque dentre tantos feiticeiros conhecidos, só quatro mulheres foram processadas durante o período de visitações, uma logo após, em 1609 e dois no século XVII? O que fez com que se tornassem vítimas do Santo ofício, que desconsiderava todas as outras denúncias? Essa pergunta só pode ser respondida por hipóteses: ou o inquisidor que tomou conhecimento dos fatos era mais sensível à questão, ou as circunstâncias exigiram alguma providência mais drástica, ou eles foram punidos para dar publicidade, para não parecer que a Inquisição não se preocupava com a questão. A exemplaridade talvez seja a melhor explicação. 
AвSTRACT: This article intends to draw a social model of the wizards who were denounced during the first two inquisitorial visits to Brazil in 1591 and in 1618 respectively, and also the delators and users of their services. It also presents the most common practices in the colony during this period and who were its practitioners. Despite the large number of accusation found, very few cases were established, which leads to seek plausible explanations for the phenomenon since these practices were condemned by the Church, the Inquisition and the laws of the kingdom, that when performed would involve the effective persecution of them.

Key Words: Wizards, Inquisitors, Denunciations.

\section{NOTAS}

1 Por costume era entendido o relato das relações que a pessoa mantinha com o(a) indiciado(a), se de amizade ou inimizade.

2 Esta informação devo à pernambucana Leda de Oliveira, que encontrei em Lisboa, cuja tese de doutorado resultou na publicação de uma reedição da História do Brasil do Frei Vicente de Salvador.

3 D. Antonio do Crato era um dos pretendentes ao trono português, vago após a morte de D. Henrique e o único a tentar derrubar D. Felipe II de Espanha, já coroado rei de Portugal.

4 Os demônios familiares eram inicialmente espíritos de antepassados que se acreditava que vinham ao mundo e davam informações, mas que depois foram sendo popularmente "transformados" em diabos particulares.

5 Sobre estes sinais distintivos, como nascer empelicado (denominação dada aos que nasciam envoltos na placenta) ver Carlo Ginzburg. Os Andarilhos do Bem. Feitiçaria e Cultos Agrários nos séculos XVI e XVII, 1990.

\section{REFERÊNCIAS}

Instituto dos Arquivos Nacionais da Torre do Tombo. INQUISIÇÃO DE LISBOA, Proc. no 10776, 3306 e 3307

Instituto dos Arquivos Nacionais dA TORRE do Tombo. INQUISIÇÃO DE LISBOA, CADERNOS DO PROMOTOR, Livro nº 228.

MENDONÇA, Heitor Furtado. Primeira Visitação do Santo Ofício às partes do Brasil. Confissões da Bahia - 1591-1592. Prefácio de Capistrano de Abreu. Rio de Janeiro: F. Briguet, 1935. 
MENDONÇA, Heitor Furtado. Primeira Visitação do Santo Ofício às Partes do Brasil. Denunciações da Bahia - 1591/1593. Introdução de Capistrano de Abreu. São Paulo: Paulo Prado, 1925.

MENDONÇA, Heitor Furtado. Primeira Visitação do Santo Ofício às partes do Brasil. Denunciações de Pernambuco- 1593-1595. Introdução de Rodolfo Garcia. São Paulo: Paulo Prado, 1929.

TEIXEIRA, Marcos. Segunda Visitação do Santo Ofício às partes do Brasil. Livro de Confissões e Ratificações da Bahia (1618-1620). Introdução de Eduardo D` Oliveira França e Sônia Siqueira. Anais do Museu Paulista, tomo XVII, 1963.

PAIVA, José Pedro. Bruxaria e superstição num País sem Caça às Bruxas. 2a ed. Lisboa: Notícias, 2002. 